\title{
バリアー上の越波による海浜変形と対策工の効果の検証

\author{
Beach Morphological Change Caused by Wave Overtopping and Verification \\ of Hard Structure to Prevent the Overwashing
}

\author{
平尾隆太郎 ${ }^{1} \cdot$ Nguyen Xuan $\operatorname{Tinh}^{2}$ ・田中 仁 $^{3}$ \\ Ryutaro HIRAO, Xuan Tinh NGUYEN and Hitoshi TANAKA
}

\begin{abstract}
Rising of sea level together with the increase of wave height during a single extreme storm event might give storm waves more possibility to get over the beach crest and bring the sediment further inland direction especially at a low barrier island. Therefore, it is important to estimate the total amount of deposited sediment on a barrier island after storm and propose any suitable countermeasures to prevent the sand deposition into the bay or lagoon. From $8^{\text {th }}$ to $10^{\text {th }}$ of October 2009, an extreme typhoon number 18 attacked the Nanakita River mouth area and there was a lots of sediment deposited inland. This study is to analyze the deposited sediment and to evaluate the effectiveness of present overwash prevention construction in the Nanakita River mouth area by using the field observation data. The estimated sediment deposition shows well agreement with the result of empirical overwash formula.
\end{abstract}

\section{1. はじめに}

現在，地球温暖化に伴う海水面の上昇が懸念されてい る.これに伴い日本の多くの海岸線が後退する可能性が ある.三村ら（1994）は，30cmの海水面上昇により国内 の砂浜の $56.6 \%$ にもぶ面積が失われると推算している. このような全国的な規模で生じる砂浜面積の減少に加 え，背後にラグーンを有するバリアー地形海浜において は, 特に大きな地形変化が生じるものと予想される.

砂丘の高さが十分に発達している海浜において越波が 生じることは稀であるが, 背後にラグーンが存在する海 浜においては砂浜の高さが十分に発達せず高波浪時に越 波が生じることがある.このようなラグーンには多様な 生物が生息することが多く, 越波による土砂移動, 堆積 による干潟の浅化, 砂質化, 干出面積の減少は大きな問 題である.よって, 干潟内の土砂堆積を防ぐためにも, 越波により生じる堆積土砂量の把握, 予測, また, 場合 によっては対策の検討が必要となる.

この対策の一例として, 宮城県蒲生干潟北部の越波防止 堤が挙げられる。この構造物は土砂堆積, 侵食による蒲生 干潟環境の変化を和らげるために設置されたものである.

これまで, 越波による海浜変形, 土砂移動に関する研 究としてWilliams (1978), 永澤 ·田中（1999）, Sallenger (2000), Donnellyら (2004, 2006), Nguyen • 田中（2007）, Nguyenら（2008）によりが行われたが, 対策工に関する検討はほとんどなされた事例がない. 2009年10月 8 日, 台風 18 号が宮城県沖に達した。これ

\begin{tabular}{|c|c|}
\hline 1 学生会員 & \\
\hline 2 正会員 & Ph.D. \\
\hline
\end{tabular}
東北大学教授工学研究科土木工学専攻
により, 宮城県を流れる七北田川河口部左岸, 蒲生干潟周 辺の海浜では越波による陸内への堆積土砂が確認された.

本研究では同海岸にて堆積土砂の生じた範囲, 堆積量 を把握するために台風 18 号来襲後に堆積土砂量の現地観 測を行った. また実測值とすでに提案されている算定式に よる計算值を比較し, 算定式の精度の検証を行った.さら に, 越波防止堤の効果を検証するために, 対策工の有無に よる土砂堆積量の差異を定量的に評価した。

\section{2. 研究対象の概要}

\section{(1) 研究対象海浜}

本研究の対象海浜の位置を図-1に示す. 宮城県仙台湾 の仙台港から七北田川河口左岸までの全長約 $1 \mathrm{~km}$ の範囲 に及ぶ海浜である. 七北田川は流域面積 $229 \mathrm{~km}^{2}$, 流路延 長 $45.0 \mathrm{~km}$ の二級河川である.

蒲生干潟（ラグーン）は, 長さ $860 \mathrm{~m}$, 最大幅 $250 \mathrm{~m}$, 水 面積 13 haの潟湖で, そのうち干潟の面積は約 5 ha である.

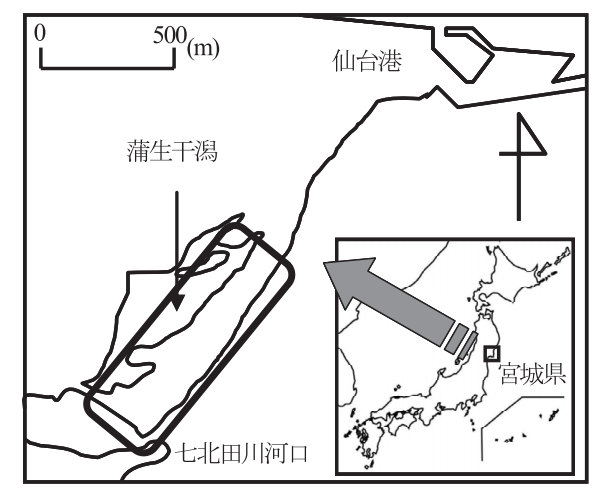

図-1 研究対象海浜 
ゴカイやハゼ類といった多様な生物の生息場となるとと もに，䬣となる豊富な底生生物をもとめシギ・チドリ類 が飛来している．また，コアジサシの繁殖地の北限，天 然記念物のコクガンの越冬地の南限として知られるなど, 貴重な渡り鳥の中継地として重要な役割を果たしている.

しかしながら, 蒲生干潟北部において越波により土砂 が干潟内部にまで堆積し, 干潟面積の減少や澪筋の消失 が発生した。また潟内部の塩分濃度変化や，それに伴う 生態系の変化が問題となった。 そこで対策工として 1998 年に $129 \mathrm{~m} に 及 ふ ゙$ 範囲に木工沈床構造の越波防止堤が設 置された。その後，この越波防止堤は1999年に $146 \mathrm{~m}$ 延 長され, さらに, 2000 年に $144 \mathrm{~m}$ の延長工事がなされ, 現在の姿となった（蒲生干潟自然再生協議会, 2006). 現在では整備後 10 年が経過しており, 部分的に陸側上段 の木枠部分が破損しているが，機能に影響を及ぼすよう な石材の崩壊や周辺地盤の変化は起こっていない．その 様子を図-2に示す。これにより, 蒲生干潟北部に限定す れば，現在では越波防止堤における土砂堆積は減少し， 海浜植生の回復が見られる。

\section{（2）台風 18 号による高波浪}

2009年10月7日から 8 日にかけて台風 18 号が日本を襲 った，台風は仙台海岸の沖合いを通過したために高波浪 が発生し, 七北田川河口部左岸に位置する蒲生干潟周辺 海浜において越波が生じた。この結果, 同地において多 量の土砂堆積が確認された.

\section{3. 現地調査}

一般に, 相前後する二つの時期の地形情報があれば, イベント前後の海浜高さを比較することにより地盤の変 化量を容易に得ることが出来る，しかし，今回のように 突発的なイベント時に押いては事前の地形デー夕取得は きわめて困難である。そこで, 本研究においては, 以下 に示す手法により砂の堆積厚の測定を行った.

現地において, コウボウムギ, ハマニンニク, ハマニ ガナの 3 種の海浜植物が確認でき, 地上にわずかながら その植物の葉が確認できる地点が見られた。植物周辺を スコップで掘ると図-3のように層から数十 $\mathrm{cm}$ の深さに植 物の存在が確認できた。 そこで, 地中に存在するこれら の植生までの深さをもとに土砂の堆積厚さを測定した. また，GPSにより植物が確認された地点の位置情報およ び土砂堆積が生じた範囲の情報を得た。調查結果を図-4 に示している. 図の左側の小さな点は, 上記の砂に埋も れた海浜植生の存在を確認した場所であり，これを囲む 曲線が越波による砂の堆積範囲を示している。 また，同 図の右半分にみられる太い点線が越波防止堤の位置を表 している.

また，光波測距儀を用いて土砂堆積後の海浜地形測量 を行い, 対象海浜の土砂堆積後のコンター図を作成した. さらに, この等高線図上に土砂堆積厚が測定された箇所 の位置をプロットし, 堆積砂厚を差引くことにより堆積

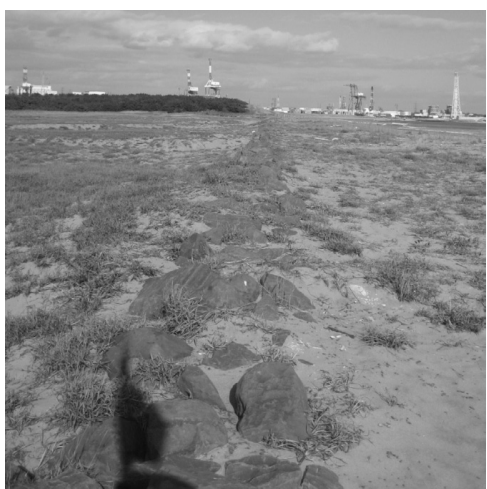

図-2 南端から見た越波防止堤(2009 年10月 10 日)

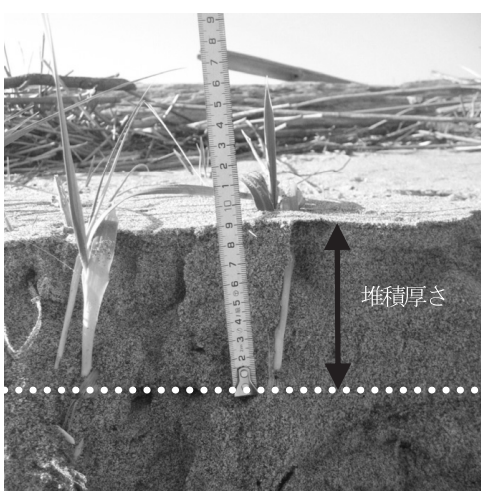

図-3 堆積厚さの測定

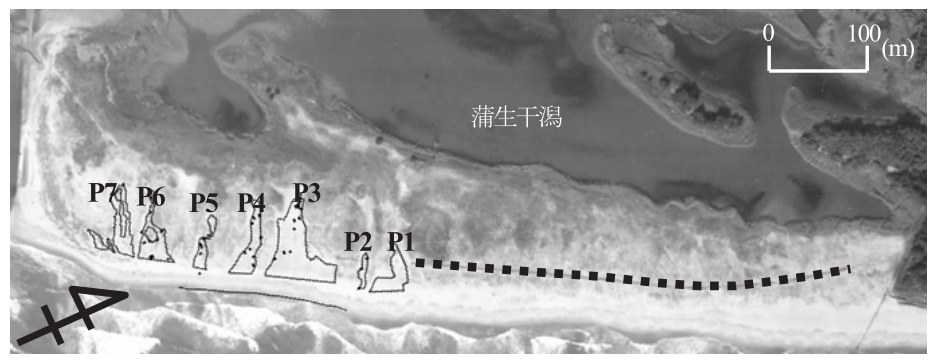

図-4 現地調查による堆積土砂の範囲と越波防止堤の位置 


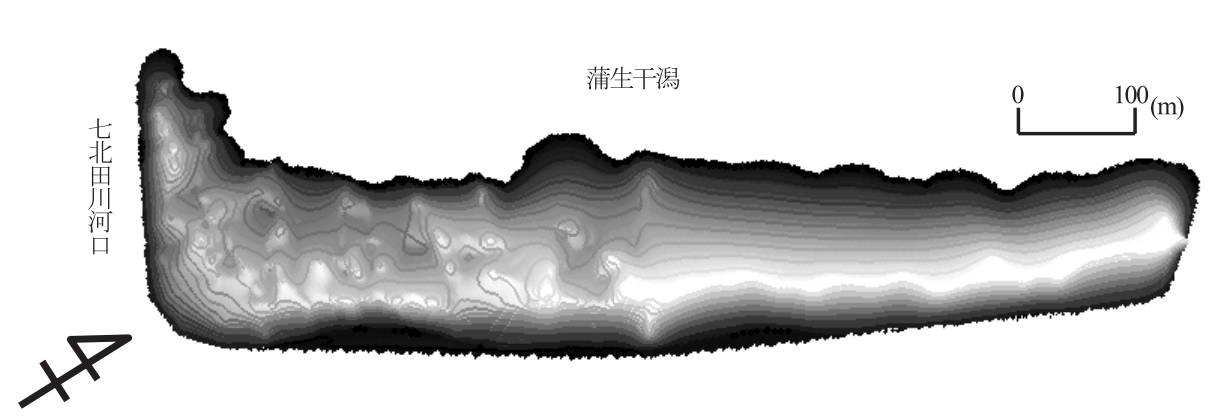

T.P. (m)

0.0-0.4

$0.4-0.8$

$0.8-1.2$

$1.2-1.6$

$1.6-2.0$

$2.0-2.4$

$2.4-2.8$

$2.8-3.2$

3.2-3.6

図-5 土砂堆積後の対象海浜における等高線図
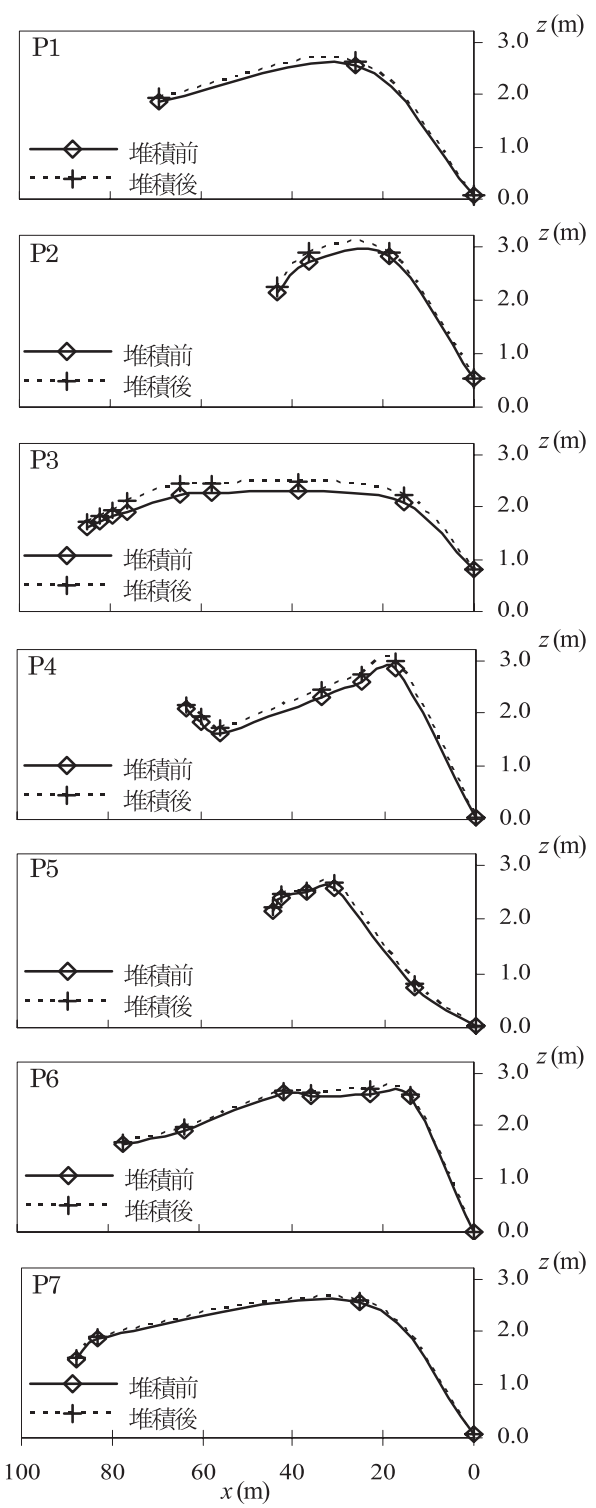

図-6 測線ごとの断面形状
前の標高を求めた.

測量より得られた標高のコンター困を図-5に示す。困 より，越波防止堤が建設されている北側の最頂部はほぼ 一様な標高であるのに対して, 南側では地形の起伏が著 しい.凸部の頂部はコウボウムギなどの植生に覆われ， 比較的長期にわたって安定しているのに対し, 凹部には より背丈の低いハマニンニクやハマニガナなどの植生が 見られる。

今回の調査で堆積が認められた土砂堆積の地形は7箇 所で, 北から順にP1, P2, ・・・とした.これらの位置 における砂浜断面図を図-6に示した。ここで，横軸は汀 線からの距離 $x$, 縦軸 $z$ は標高（T.P.）を表している。こ の図における標高の変化量が汀線から岸向き方向の単位 幅における堆積砂量にあたる。

前述のように，それぞれの測線においては，局所的な 海浜地形を反映して扇状に広がる堆積地形が見られた (図-4)。そこで，全ての堆積量を合算したところ，おお よそ930 $\mathrm{m}^{3}$ の体積であると見積もられた。

\section{4. 堆積砂量算定式の適用}

\section{（1）算定式について}

越波により生じる堆積砂量の算定のため, Nguyen ・田 中（2007）の以下に示す式を用いた. 同式は, 越波流量 が波の最大遡上高さ $R$ と砂丘最頂部高さ $H_{c}$ との差に比例 するとし, 越波の継続時間 $t_{D}$, 砂丘高さに依存した底質 供給の多寡を考慮して経験的に得られたものである.

$$
Q=0.0011 \frac{H_{c}}{R} \frac{t_{D}}{T}\left(R-H_{c}\right)^{2} \quad\left(\mathrm{~m}^{3} / \mathrm{m}\right)
$$

ここで, $Q$ : 単位幅あたりの堆積砂量, $H_{c}$ : 砂丘最頂部 高さ $(\mathrm{m}), R$ : 最大遡上高さ $(\mathrm{m}), t_{D}: R>H_{c}$ となる時間 の長さ $(\mathrm{s}), T$ : 波の周期 $(\mathrm{s})$ である. なお, $H_{c}$ について は, 実測により得られた堆積前の砂丘最頂部の高さを用 いている。また, 式（1）を得る際に適用した海浜の底 質粒径 $d_{50}$ は $0.17 \mathrm{~mm} \sim 0.44 \mathrm{~mm}$ の範囲に存在しているが式 の簡略化のため底質粒径の大小は考慮していない。 $R$ に 関してはHunt（1959）による次式を用いた。 


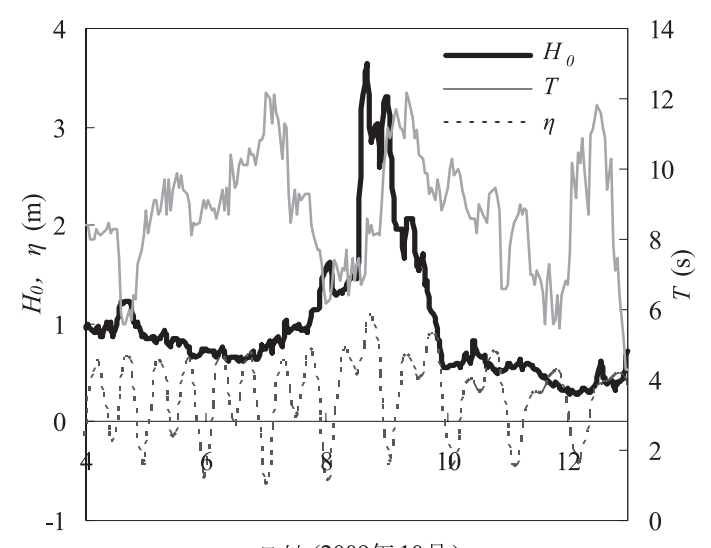

日付 (2009年10月)

図-7 台風 18 号による波の各水理量諸元

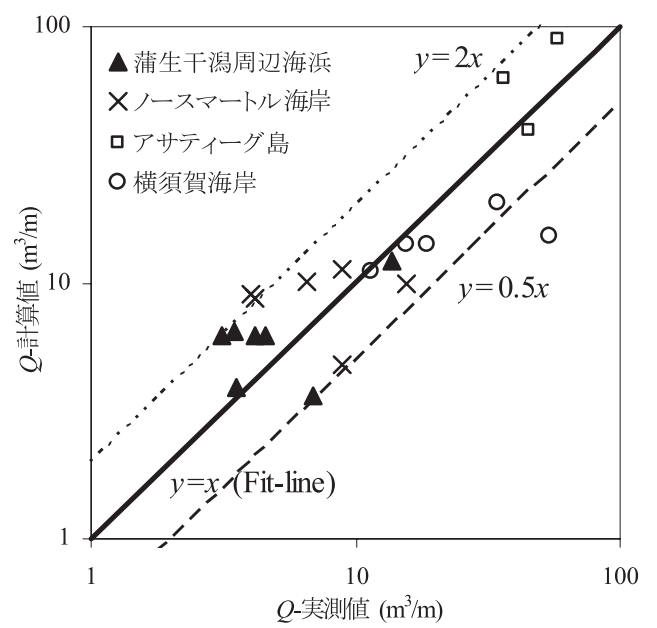

図-8 堆積土砂量の実測値と計算値の比較

$$
R=\tan \alpha \sqrt{H_{0 r m s} L_{0}}
$$

ここで, $\tan \alpha$ : 前浜勾配, $H_{0 r m s}$ : 沖波の二乗平均平方根 波高， $L_{0}$ : 沖波波長である。なお，式（1）の適用に当 たっては実測潮位を考慮し, 海水面から砂丘最頂部まで の高さの時間変化を加味して計算を行っている．また， 式（2）中の前浜勾配はそれぞれの測線にて実測により 得られた值を使用した。

\section{（2）対象期間および収集されたデータ}

対象期間は台風 18 号通過4日前の 2009年10月4日午前 0 時から通過 4 日後までの午前 0 時〜 10 月 13 日午前 0 時ま でとした。この期間で，式（2）による遡上高さが砂丘 を越える時間を求めたところ, 最長はP 3 における 69 時 間であった。 また，有義波高，周期についてはナウファ スの仙台新港観測点におけるデータを用いた。潮位に関 しては気象庁・鮎川検潮所の実測潮位を使用した。それ ぞれの值の時系列変化を図-7にまとめて示した。なお， 図中において $\eta$ は実測潮位を表す。

\section{（3）算定結果と実測値の比較}

今回の研究対象領域について式（1）を実測の際に土 砂堆積が確認されたP1からP7の測線に適用し，それぞ れの測線上における単位幅あたりの堆積砂量を求めた. 実測值と計算值とを比較したグラフを図-8に示す。また， 今回の研究対象海浜だけでなく, Nguyen・田中（2008） による他の海浜における実測值，計算值も同様にプロッ トした。

これを見ると, 今回の台風 18 号の高波浪による土砂堆 積について，実測值と計算值は 0.5 倍 2 倍の範囲おさま っていることが分かる.これは一回の高波浪イベントに 対しては十分な精度であるといえる。ただし, 式（1） の有する問題点として, 各測線によって異なる砂丘上の 微地形や海浜地形の相違を加味していないことなどが挙 げられる。特に，P5およびP7に関しては，複雑な凹凸 地形に応じて分岐して土砂が堆積している様子が現地調 査を行った際に確認されており, それが原因で他の測線 と比較して計算值が過小評価になったと考えられる.

Nguyen ら（2008）らは，自身による宮城県横須賀海岸 における事例の他に，他の研究者によりなされたノース マートル海岸（Eiser・Birkemeier，1991），アサティーグ 島（Larsonら，2004）における観測值について報告して いる.これらのデー夕の観測対象箇所, 観測期間での各 水理量の最大值の值を今回の観測結果とともに表-1に示 す.図-8によれば，これらのデータに関しても上記の二 直線内に収まり良好な一致を示している。なお，表-1に 関して蒲生周辺海浜の值と横須賀海岸を比較してみる と，それぞれの值が類似しているが有義波高のみ差が大 きい. したがって，今回示したオーダーの範囲内であれ ば波高条件が変動しても式（1）が適用できるといえる. また， $t_{D}$ を比較するとそれぞれ 8 時間 283時間と差が大 きいにも関わらず実測值と計算值において一致が確認で きる。これにより越波の継続時間の長短に関わらず式 （1）が適用可能である. また，ノースマートル海岸，横 須賀海岸について見ると, 堆積土砂量の計算值はおおよ そ $Q=10 \mathrm{~m}^{3} / \mathrm{m}$ を境に分布し, それぞれ過大, 過小評価に

表-1 堆砂イベントと各水理量の最大值

\begin{tabular}{c|c|c|c|c|c|c}
\hline 地点名 & $\begin{array}{c}\text { ハリケーン } \\
\text { 等の名称 }\end{array}$ & $\begin{array}{c}H_{0} \\
(\mathrm{~m})\end{array}$ & $\begin{array}{c}T \\
(\mathrm{~s})\end{array}$ & $\begin{array}{c}\eta \\
(\mathrm{m})\end{array}$ & $\begin{array}{c}R \\
(\mathrm{~m})\end{array}$ & $\begin{array}{c}t_{D} \\
(\mathrm{~h})\end{array}$ \\
\hline $\begin{array}{c}\text { 蒲生干潟周辺海岸 } \\
\text { (本研究) }\end{array}$ & $\begin{array}{c}\text { 台風18号 } \\
(2009 \text { 年 })\end{array}$ & 3.7 & 12.2 & 1.09 & 3.24 & 69 \\
\hline $\begin{array}{c}\text { ノースマートル海岸 } \\
(\text { Eiser・Birkemeir, 1991) }\end{array}$ & $\begin{array}{c}\text { Hugo } \\
(1989 \text { 年 })\end{array}$ & 4.8 & 10.8 & 2.13 & 4.65 & 8 \\
\hline $\begin{array}{c}\text { アサティーグ島 } \\
\text { (Larsonら, 2004) }\end{array}$ & $\begin{array}{c}\text { Northeaster } \\
(1998 \text { 年 })\end{array}$ & 2.9 & 16.0 & 1.91 & 5.38 & 283 \\
\hline $\begin{array}{c}\text { 横須賀海岸 } \\
\text { (Nguyen・田中, 2007) }\end{array}$ & $\begin{array}{c}\text { 台風18号 } \\
(2006 \text { 年) }\end{array}$ & 8.4 & 11.5 & 1.13 & 5.23 & 49 \\
\hline
\end{tabular}




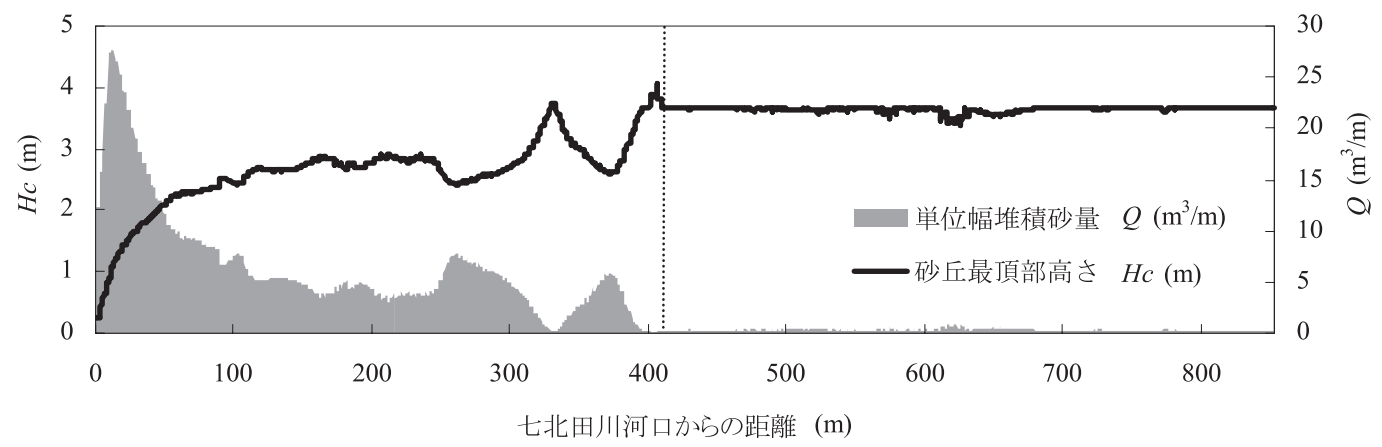

図-9 砂丘部における最頂部の高さと算定された堆積土砂量

なっている。しかし，今回の研究により，算定式の適用 できる範囲が拡大されたことが図-8より見て取れる.

\section{5. 越波防止堤の効果}

式（1）から明らかなように，堆積土砂量は砂丘部高 さと強い関係を有している。そこで，図-5に示した地形 データから, 砂丘最頂部高さ $H_{c}$ の沿岸方向分布を求め, 図-9に示した。 また，この $H_{c}$ の值を式（1）に代入し, それぞれの場所での土砂堆積量を算定した。

図-9によれば，越波防止堤が存在する区間は存在しな い区間に比べて顕著に標高が高いわけではないものの, 越波防止堤の存在により地形に起伏が少なく, ほぼ一様 な標高が維持されている。一方，越波防止堤がない区域 においては砂丘に起伏があるため, その谷部より波が浸 入し土砂堆積が生じやすいことが確認された。また，現 地にてそれぞれの区間の特徴を比較したところ, 越波防 止堤が存在する区間においては，構造物より海側ですで に顕著な堆積が見られ，構造物が存在しない区間と比べ 多くのハマニンニクなどの植生が確認された。これらの 植生は波の遡上に対して粗度として作用し, 波エネルギ 一の消散に寄与しているものと考えられる.

\section{6. おわりに}

以下に本研究より得られた主要な結論を示す.

（1）2009年10月 8 日に来襲した台風 18 号によって蒲生干 潟周辺海浜に越波が生じ土砂堆積が確認された。現地 調査によりそれぞれの測線上における堆積砂量の実測 值を得た。また，堆積砂量の合計は $930 \mathrm{~m}^{3}$ となった。

（2）既存の算定式により堆積砂量の計算值を得，その実 測值と計算值を比較した結果，0.5 倍〜2倍の範囲に収 まっており, 台風 18 号のような波浪条件においても既 存の算定式が適用できることが分かった.

（3）それぞれの地点において堆積砂量を求め, 越波防止 堤の効果を検証した。構造物の設置により，砂丘標高 が維持され，越波およびそれに伴う土砂堆積を防止す
る役割を果たしていることが明らかとなった.

謝辞：本研究を実施するに当たり，日本学術振興会科学 研究費（No.2136023, No.2109287）の補助を受けた。こ こに記して，謝意を表する。

\section{参 考 文 献}

蒲生干潟自然再生協議会（2006）：蒲生干潟自然再生全体構想, $52 \mathrm{p}$.

Nguyen Tinh Xuan ・田中 仁（2007）：越波による海浜変形の 現地観測と数值計算, 海岸工学論文集, 第 54巻, pp.681-685.

Nguyen Tinh Xuan ·田中 仁 · C. Donnelly - M. Larson （2008）：現地資料に基づく越波による土砂堆積量の定式 化とその検証, 海岸工学論文集, 第 55 巻, pp.476-480.

三村信男 - 井上響子 - 幾世橋慎 · 泉宮尊司 - 信岡尚道 （1994）：砂浜に対する海面上昇の影響評価（2）－予測モ デルの妥当性の検証と全国規模の評価, 海岸工学論文集, 第 41 巻, pp.1161-1165.

永澤 豪・田中 仁（1999）：高波浪時の越波による海浜地形 変化, 海岸工学論文集, 第 46巻, pp.561-565.

Donnelly, C., N.C. Kraus and M. Larson (2004) : Coastal overwash, Part 1: Overwash of Processes. Regional Sediment Management Demonstration Program Technical Note, ERDC/RSM-TN-14, U.S. Army Engineer Researcher and Development Center, Vicksburg, MS.

Donnelly, C., N.C. Kraus and M. Larson (2006) : State of knowledge on measurement and modelling of coastal overwash, Journal of Coastal Research, Vol. 22, pp. 965-991.

Eiser, W.C., and M. Birkemeier (1991): Beach profile response to Hurricane Hugo, Proceedings Coastal Sediments '91, pp.16811696.

Hunt, I.A. (1959) : Design of seawalls and breakwaters, J. Waterways and Harbors Division, Vol.85, No.WW3, pp.123152.

Larson, M., R.A. Wise and N.C. Kraus (2004) : Coastal Overwash. Part 2: Upgrade to SBEACH, Regional Sediment Management Demonstration Technical Note, ERDC/RSM-TN-15, U.S. Army Engineer Research and Development Center, Vicksburg, MS.

Shallenger, A.H. Jr. (2000) : Storm impact scale for barrier islands, Journal of Coastal Research, Vol.16, No.3, pp. 890-895.

Williams, P.L. (1978) : Laboratory development of a predictive relationship for washover volume on barrier island coastlines, Master Thesis, Department of Civil Engineering, University of Delaware, Newark, $154 \mathrm{p}$. 